\title{
Meta-Analysis of the Effect of High-Intensity Interval Training in Increasing High-Density Lipoprotein Levels in Type 2 Diabetes Mellitus Patients
}

\author{
Sela Putri Adelita'), Eti Poncorini Pamungkasari²), Bhisma Murti1) \\ 1)Masters Program in Public Health, Universitas Sebelas Maret \\ ${ }^{2)}$ Department of Public Health, Faculty of Medicine, Universitas Sebelas Maret
}

\section{ABSTRACT}

Background: Diabetes mellitus is one of the second biggest health problems. The International Diabetes Federation said that diabetes currently affects 382 million people worldwide, with type 2 diabetes mellitus (DM) being the largest prevalence of $85-95 \%$ of the diabetes population. This study aimed to estimate the effect of highintensity interval training (HIIT) on increasing levels of high-density lipoprotein in patients with type 2 diabetes mellitus based on the results of several previous studies.

Subjects and Method: This study was a metaanalysis and systematic study, with the following PICO Population =type 2 diabetes mellitus patients aged 35-65 years. Intervention=HIIT. Comparison $=$ No HIIT . Outcome $=$ increased levels of high-density lipoprotein. The articles used in this study were obtained from several databases, including PubMed, ScienceDirect, and Google Scholar. The keywords for finding articles were: "HIIT" OR "High-Intensity interval Training" OR "Diabetes Mellitus" OR "High-Density Lipopro- tein" AND "Randomized Controlled Trial". The articles included in this study were full-text with a randomized controlled trial. Articles were analyzed by PRISMA flow chart and RevMan 5.3. Results: A total of 9 articles reviewed in this meta-analysis study originated from New York, Canada, France, Thailand, Berlin, Denmark, Australia, and the United Kingdom. Studies showed that high intensity interval training increased the levels of high density lipoproteins (Mean Difference $=0.01 ; 95 \% \mathrm{CI}=0.31$ to $0.30 ; \mathrm{p}=0.970$ ).

Conclusion: High intensity interval training increases high-density lipoprotein levels.

Keywords: High intensity interval training, type 2 diabetes mellitus, high density lipoprotein

\section{Correspondence:}

Sela Putri Adelita, Masters Program In Public Health, Universitas Sebelas Maret. Jl. Ir. Sutami 36A, Surakarta 57126, Central Java. Email: Selaadelita558@gmail.com.

Cite this as:

Adelita SP, Pamungkasari EP, Murti B (2020). Meta-Analysis of the Effect of High-Intensity Interval Training on Increased High-Density Lipoprotein Levels in Type 2 Diabetes Mellitus Patients. Indones J Med. 05(04): 272281. https://doi.org/10.26911/theijmed.2020.05.04.02.

cc) (†) (-) Indonesian Journal of Medicine is licensed under a Creative Commons

EY NC SA Attribution-NonCommercial-ShareAlike 4.0 International License.

\section{BACKGROUND}

Non-communicable disease (NCD) is the leading cause of death and disability in the world. $71 \%$ of global deaths are due to non-disease contagious diseases that claim 40 million lives each year. One of the non-communicable diseases that cause the highest mortality is Diabetes mellitus (WHO, 2016).

Diabetes mellitus is one of the second biggest health problems. Data from a global study in 2011 showed the number of people with diabetes mellitus had reached 366 million people. If no action is taken, this number will increase to 522 million in 2030, as many as 183 million people do not realize that they have diabetes with the highest number between the ages of 40-59 years (IDF, 2011).

Type 2 diabetes mellitus (DM) is defined as a bihormone metabolic disorder 
characterized by insufficient insulin secretion and abnormal glucagon secretion (Unger et al., 2019).

Diabetes mellitus is also called the silent killer because this disease can affect all organs of the body with various complaints such as heart disease, kidney disease, blood vessel disorders, wounds that are difficult to heal and gangrene, stroke, and so on, besides spending diabetes mellitus funds reaching 465 billion USD (IDF, 2011).

The International Diabetes Federation stated that currently, diabetes affects 382 million people worldwide, with type $2 \mathrm{DM}$ being the largest prevalence consisting of 85$95 \%$ of the diabetes population (Goedecke, 2015).

Various countries currently dominate the largest diabetes prevalence in the world from several continents, including the Asian continent. China occupies the first position with a prevalence of 114.9 million sufferers, Indonesia ranks 6 in the world with a prevalence of 10.3 million sufferers, the American continent 30.2 million sufferers and how the top 10 global data The highest prevalence of diabetes is dominated by European countries (IDF, 2017).

Overweight and obesity are major risk factors for a number of chronic diseases, including type 2 DM. This prevalence is associated with a healthy lifestyle, increased obesity, and increased urbanization with greatly reduced physical activity (Shaw, 2010).

Physical exercise is one of the first-line treatments in preventing and treating type 2 diabetes and its complications. Physical activity affects glycemic control, cardiometabolic risk, and psychological well-being (Colberg et al., 2010).

Several physical exercises are recommended by the American Diabetes Association (ADA) and the American College of Sports Medicine in 2013, type 2 DM sufferers are recommended to do at least moderate to vigorous aerobics with a minimum of 150 minutes per week with 2-3 sessions per week according to $50-70 \%$ of maximum heart rate.

However, HIIT, which consists of several high-intensity exercises in addition to rest or recovery intervals, has a superior effect on improving glycemic control and is also associated with other health problems (Ciolac et al., 2015).

The high incidence of type 2 diabetes mellitus is known that physical activity greatly affects the prevention and treatment of type $2 \mathrm{DM}$ and HIIT is one of the physical activities that are considered effective to reduce DM whose prevalence continues to increase. This study aimed to review the effect of HIIT on the increased lipoprotein levels in type $2 \mathrm{DM}$.

\section{SUBJECTS AND METHOD \\ 1. Study Design}

This was a systematic and meta-analysis study. The articles were obtained from PubMed, ScienceDirect, and Google Scholar databases. Keywords for searching articles were "HIIT" OR "High-Intensity interval Training" OR "Diabetes Mellitus" OR "HighDensity Lipoprotein "AND" Randomized Controlled Trial."

\section{Study Variables}

Inclusion Criteria. The articles included in this study were a full paper article with a randomized controlled trial study design. The study subjects were people with type 2 DM aged $35-65$ years. Selected articles discussed HIIT with the outcome of increasing HDL levels.

Exclusion Criteria. The articles used in this study were articles with non-RCT study designs, articles that were not full-text, articles published before 2010, and articles that were not published in English.

\section{Operational Definition of Variables} The article search was carried out by considering the eligibility criteria defined using the 
PICO model. The study population was type 2 DM patients aged 35-65 years, the intervention was HIIT, the comparison was no HIIT, and the outcome was an increase in HDL levels.

High Intensity Interval Training was a training method that had the advantage of shortening the training time, minimizing the effect of injury on the musculoskeletal system, and also flexible. Instrument: International Physical Activity Questionnaire (IPAQ) with a categorical measuring scale.

High density lipoprotein is a high density lipoprotein and contains a lot of protein and less fat with. The instrument used was the lipid pro with a continuous measuring scale.

\section{Data Analysis}

Data processing was carried out by a Review Manager (RevMan 5.3) by calculating the mean difference to determine the study model that was combined and formed the final meta-analysis result.

\section{RESULTS}

The process of searching for articles by searching through a database with journals can be seen in Figure 1.

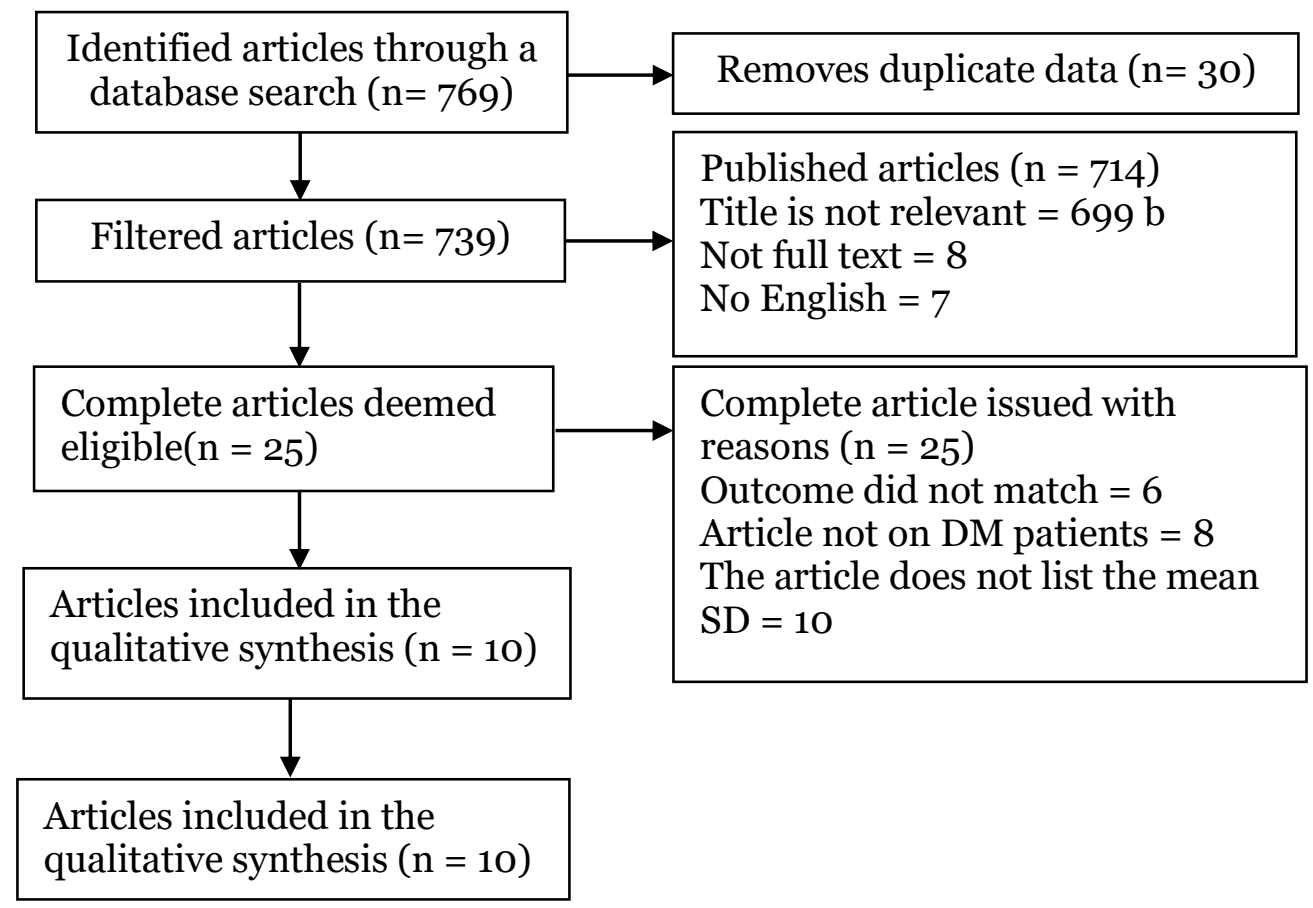

Figure 1. PRISMA diagram flow

Articles reviewed in this study were obtained from 4 continents, i.e. America, Europe, Australia, and Asia. The forest plot (Figure 3) shows that high intensity interval training 0.01 times reduced HDL levels in patients with type 2 diabetes mellitus compared with no HIIT and was not statistically significant $(\mathrm{p}=0.970)$. The study data's heterogeneity showed I $2=70 \%$ so that the distribution of the data was stated to be heterogeneous (random effect model).
The funnel plot (Figure 4) shows a publication bias characterized by the asymmetry of the right and left plots where 4 plots were on the right, and 5 plots were on the left. The plot on the left of the graph had a standard error between 0.2 and 0.6 , and the plot on the right had a standard error between 0.2 and 0.6. Bias also occurred from the imbalance between the distances between studies on both the right and left of the funnel plot. 
Adelita et al./ Effect of HIIT in Increasing of HDL Level in Type 2 DM

Figure 3. The Assessment of Study Quality

\begin{tabular}{|c|c|c|c|c|c|c|c|c|c|c|}
\hline Publication & Cohort & $\begin{array}{l}\text { With } \\
\text { the } \\
\text { control } \\
\text { group }\end{array}$ & $\begin{array}{l}\text { Pre/post } \\
\text { Interven- } \\
\text { tion }\end{array}$ & $\begin{array}{l}\text { Random } \\
\text { assign- } \\
\text { ment }\end{array}$ & $\begin{array}{l}\text { Random } \\
\text { selection of } \\
\text { assignment }\end{array}$ & $\begin{array}{l}\text { Sample } \\
\text { size } \\
(>100)\end{array}$ & $\begin{array}{l}\text { Follow up } \\
\text { rate }>80 \%\end{array}$ & $\begin{array}{l}\text { Comparable } \\
\text { sociodemo- } \\
\text { graphic } \\
\text { between } \\
\text { study arms }\end{array}$ & $\begin{array}{l}\text { Comparable } \\
\text { baseline out- } \\
\text { come mea- } \\
\text { sures between } \\
\text { study arms }\end{array}$ & Total \\
\hline $\begin{array}{l}\text { Balducci et } \\
\text { al. (2012) }\end{array}$ & 1 & 1 & 1 & 1 & 1 & 1 & 1 & 1 & 1 & 9 \\
\hline $\begin{array}{l}\text { Terada et al. } \\
\text { (2012) }\end{array}$ & 1 & 1 & 1 & 1 & 1 & 1 & 1 & 1 & 1 & 9 \\
\hline $\begin{array}{l}\text { Maillard et } \\
\text { al. (2016) }\end{array}$ & 1 & 1 & 1 & 1 & 1 & 1 & 1 & 1 & 1 & 9 \\
\hline $\begin{array}{l}\text { Mitranun et } \\
\text { al. (2014) }\end{array}$ & 1 & 1 & 1 & 1 & 1 & $\mathrm{O}$ & 1 & 1 & 1 & 8 \\
\hline $\begin{array}{l}\text { Stoa et al. } \\
(2017)\end{array}$ & 1 & 1 & 1 & 1 & 1 & $\mathrm{O}$ & 1 & 1 & 1 & 8 \\
\hline $\begin{array}{l}\text { Karstoft et al. } \\
\text { (2012) }\end{array}$ & 1 & 1 & 1 & 1 & 1 & $\mathrm{O}$ & 1 & 1 & 1 & 8 \\
\hline $\begin{array}{l}\text { Ramos et al. } \\
\text { (2016) }\end{array}$ & 1 & 1 & 1 & 1 & 1 & $\mathrm{O}$ & 1 & 1 & 1 & 8 \\
\hline $\begin{array}{l}\text { Backx et al. } \\
(2013)\end{array}$ & 1 & 1 & 1 & 1 & 1 & $\mathrm{O}$ & 1 & 1 & 1 & 8 \\
\hline $\begin{array}{l}\text { Madsen et al. } \\
(2016)\end{array}$ & 1 & 1 & 1 & 1 & 1 & $\mathrm{O}$ & 1 & 1 & 1 & 8 \\
\hline
\end{tabular}

a. High-intensity interval training onthe increase of density lipoprotein

9 The article proved that there was a link between HIIT and increased HDL levels in type 2 DM patients

\begin{tabular}{|c|c|c|c|c|c|c|c|}
\hline $\begin{array}{l}\text { Author } \\
\text { (Year) }\end{array}$ & Country & Study Design & Sample & $\begin{array}{l}\text { P } \\
\text { (Population) }\end{array}$ & (Intervention) & $\begin{array}{l}\mathrm{C} \\
\text { (Comparison) }\end{array}$ & $\begin{array}{l}\text { O } \\
\text { (Outcome) }\end{array}$ \\
\hline $\begin{array}{l}\text { Balducci et al. } \\
\text { (2012). }\end{array}$ & $\begin{array}{l}\text { New York } \\
\text {. }\end{array}$ & $\begin{array}{l}\text { Randomized } \\
\text { Controlled } \\
\text { Trial. }\end{array}$ & $\begin{array}{l}\text { HIIT: } 161 \\
\text { No HIIT:142 }\end{array}$ & $\begin{array}{l}\text { Patients with } \\
\text { type } 2 \\
\text { diabetes, aged } \\
33-55 \text { years. }\end{array}$ & $\begin{array}{l}\text { Saw at the effects of high } \\
\text { exercise intensity training } \\
\text { (HIIT) with low to moderate- } \\
\text { intensity exercise in patients } \\
\text { with type } 2 \text { diabetes mellitus } \\
\text { on glycemic control, LDL } \\
\text { lipids, HDL *, triglycerides, } \\
\text { total cholesterol, measured } \\
\text { before and after in both } \\
\text { groups. }\end{array}$ & $\begin{array}{l}\text { Did not see the effect of } \\
\text { high exercise intensity } \\
\text { training, type } 1 \text { diabetes } \\
\text { mellitus patients did not } \\
\text { see control on glycemic, } \\
\text { lipid, not in two groups. }\end{array}$ & $\begin{array}{l}\text { Increased } \\
\text { levels of } \\
\text { High density } \\
\text { lipoprotein } \\
\text { (HDL) }\end{array}$ \\
\hline
\end{tabular}


Adelita et al./ Effect of HIIT in Increasing of HDL Level in Type 2 DM

\begin{tabular}{|c|c|c|c|c|c|c|c|}
\hline $\begin{array}{l}\text { Author } \\
\text { (Year) }\end{array}$ & Country & Study Design & Sample & $\begin{array}{l}\mathbf{P} \\
\text { (Population) }\end{array}$ & I & $\begin{array}{l}\text { C } \\
\text { (Comparison) }\end{array}$ & $\begin{array}{l}\text { O } \\
\text { (Outcome) }\end{array}$ \\
\hline $\begin{array}{l}\text { Terada et al. } \\
\text { (2012). }\end{array}$ & Canada & $\begin{array}{l}\text { Randomized } \\
\text { Controlled } \\
\text { Trial. }\end{array}$ & $\begin{array}{l}\text { HIIT : } 63 \\
\text { No HIIT }: 63\end{array}$ & $\begin{array}{l}\text { Patients with } \\
\text { type } 2 \\
\text { diabetes, aged } \\
33-55 \text { years. }\end{array}$ & $\begin{array}{l}\text { Compared high intensity } \\
\text { versus moderate interval } \\
\text { training eligibility sustained or } \\
\text { moderate-intensity exercise } \\
\text { (MI-CE) in patients with type } 2 \\
\text { diabetes (T2D) on glycated } \\
\text { haemoglobin, HbA1c and body } \\
\text { composition (Baseline blood } \\
\text { profile, anthropometric } \\
\text { measurements, HDL * body } \\
\text { fat, LDL, cholesterol, } \\
\text { triglycerides. }\end{array}$ & $\begin{array}{l}\text { Did not look at the } \\
\text { feasibility of high to } \\
\text { moderate intensity interval } \\
\text { training, not on } \\
\text { hemoglobin HbA1c and did } \\
\text { not look at body } \\
\text { composition. }\end{array}$ & $\begin{array}{l}\text { Increased } \\
\text { levels of } \\
\text { High density } \\
\text { lipoprotein } \\
\text { (HDL) }\end{array}$ \\
\hline $\begin{array}{l}\text { Maillard et al. } \\
\text { (2016) }\end{array}$ & Prancis & $\begin{array}{l}\text { Randomized } \\
\text { Controlled } \\
\text { Trial. }\end{array}$ & $\begin{array}{l}\text { HIIT :161 } \\
\text { Tidak HIIT : } \\
142\end{array}$ & $\begin{array}{l}\text { Patients with } \\
\text { type } 2 \\
\text { diabetes, aged } \\
\text { 45-39 years. }\end{array}$ & $\begin{array}{l}\text { This study compared the } \\
\text { effects of high-intensity } \\
\text { interval training (HIIT) and } \\
\text { moderate-intensity continuous } \\
\text { exercise (MICT) on whole- } \\
\text { body fat mass. Fasting glucose, } \\
\text { total cholesterol, HDL *, and } \\
\text { LDL and stomach (FM) in } \\
\text { women with type } 2 \text { diabetes } \\
\text { (T2D). }\end{array}$ & $\begin{array}{l}\text { Did not compare the effects } \\
\text { of high-intensity interval } \\
\text { training (HIIT) and conti- } \\
\text { nuous to moderate training } \\
\text { (MICT) instead of looking } \\
\text { at the effects on body mass } \\
\text { and belly fat. And not in } \\
\text { type } 2 \text { DM patients. }\end{array}$ & $\begin{array}{l}\text { Increased } \\
\text { levels of } \\
\text { High density } \\
\text { lipoprotein } \\
\text { (HDL) }\end{array}$ \\
\hline $\begin{array}{l}\text { Mitranun et al. } \\
\text { (2014). }\end{array}$ & Thailand & $\begin{array}{l}\text { Randomized } \\
\text { Controlled } \\
\text { Trial. }\end{array}$ & $\begin{array}{l}\text { HIIT : } 14 \\
\text { Tidak HIIT : } \\
14\end{array}$ & $\begin{array}{l}\text { Patients with } \\
\text { type } 2 \\
\text { diabetes, aged } \\
50-70 \text { years. }\end{array}$ & $\begin{array}{l}\text { Determined the effect of HIIT } \\
\text { vs self-coordinated training on } \\
\text { glycemic control of HbA1c, } \\
\text { total cholesterol, HDL }{ }^{*}, \mathrm{LDL}, \\
\text { triglycerides, nitrin oxcide. }\end{array}$ & $\begin{array}{l}\text { Did not determine the } \\
\text { effect of HIIT training vs } \\
\text { coordinated self-training } \\
\text { and did not see the effect } \\
\text { on glycemic control. }\end{array}$ & $\begin{array}{l}\text { Increased } \\
\text { levels of } \\
\text { High density } \\
\text { lipoprotein } \\
\text { (HDL) }\end{array}$ \\
\hline $\begin{array}{l}\text { Stoa et al. } \\
(2017) \text {. }\end{array}$ & Berlin & $\begin{array}{l}\text { Randomized } \\
\text { Controlled } \\
\text { Trial. }\end{array}$ & $\begin{array}{l}\text { HIIT : } 19 \\
\text { Tidak HIIT : } \\
19\end{array}$ & $\begin{array}{l}\text { Patients with } \\
\text { type } 2 \\
\text { diabetes, aged } \\
45-59 \text { years }\end{array}$ & $\begin{array}{l}\text { Examined the effect } \\
\text { comparison after being given a } \\
\text { HIIT training program and } \\
\text { moderate intensity training on } \\
\text { maximal oxygen uptake } \\
\text { (VO2max), symbol of lactate } \\
\text { (LT), blood pressure (BP), and } \\
\text { blood lipid profiles (HDL *, } \\
\text { LDL, and triglycerides) of } \\
\text { patients with T2D. }\end{array}$ & $\begin{array}{l}\text { Did not compare the effects } \\
\text { of a HIIT training program } \\
\text { and moderate intensity } \\
\text { training. Did not study } \\
\text { maximal oxygen uptake } \\
\text { (VO2max), lactate symbol } \\
\text { (LT), blood pressure (BP), } \\
\text { and blood lipid profiles of } \\
\text { HDL, LDL, and } \\
\text { triglycerides) and type } 2 \\
\text { DM patients. }\end{array}$ & $\begin{array}{l}\text { Increased } \\
\text { levels of } \\
\text { High density } \\
\text { lipoprotein } \\
\text { (HDL) }\end{array}$ \\
\hline
\end{tabular}


Adelita et al./ Effect of HIIT in Increasing of HDL Level in Type 2 DM

\begin{tabular}{|c|c|c|c|c|c|c|c|}
\hline $\begin{array}{l}\text { Author } \\
\text { (Year) }\end{array}$ & Country & Study Design & Sample & $\begin{array}{l}\mathbf{P} \\
\text { (Population) }\end{array}$ & I & $\begin{array}{l}\mathrm{C} \\
\text { (Comparison) }\end{array}$ & $\begin{array}{l}\text { O } \\
\text { (Outcome) }\end{array}$ \\
\hline $\begin{array}{l}\text { Karstoft et al. } \\
\text { (2012). }\end{array}$ & Denmark & $\begin{array}{l}\text { Randomized } \\
\text { Controlled } \\
\text { Trial. }\end{array}$ & $\begin{array}{l}\text { HIIT : } 12 \\
\text { Tidak HIIT : } 8\end{array}$ & $\begin{array}{l}\text { Patients with } \\
\text { type } 2 \\
\text { diabetes, aged } \\
\text { 35-55 years }\end{array}$ & $\begin{array}{l}\text { Saw the effects of high- } \\
\text { intensity training (HIIT) with } \\
\text { low to moderate intensity } \\
\text { exercises on physical fitness, } \\
\text { body composition, and } \\
\text { glycemic control (fasting } \\
\text { glucose, HbA1c, HDL *, LDL } \\
\text { and triglycerides in patients } \\
\text { with type } 2 \text { diabetes mellitus. }\end{array}$ & $\begin{array}{l}\text { Did not see an effect on } \\
\text { high intensity training } \\
\text { (HIIT) with low to mode- } \\
\text { rate intensity training. Did } \\
\text { not examine physical fit- } \\
\text { ness or body composition } \\
\text { and do not analyze glyce- } \\
\text { mic control (fasting } \\
\text { glucose, HbA1c, HDL, LDL } \\
\text { and triglycerides. } \\
\text { Not in patients with type } 2 \\
\text { diabetes mellitus. }\end{array}$ & $\begin{array}{l}\text { Increased } \\
\text { levels of } \\
\text { High density } \\
\text { lipoprotein } \\
\text { (HDL) }\end{array}$ \\
\hline $\begin{array}{l}\text { Ramos et al. } \\
(2016) .\end{array}$ & Australia & $\begin{array}{l}\text { Randomized } \\
\text { Controlled } \\
\text { Trial. }\end{array}$ & $\begin{array}{l}\text { HIIT : } 9 \\
\text { Tidak HIIT : } 6\end{array}$ & $\begin{array}{l}\text { Patients with } \\
\text { type } 2 \\
\text { diabetes, aged } \\
\text { 37-57 years. }\end{array}$ & $\begin{array}{l}\text { This study aimed to see the } \\
\text { impact of HIIT on proinsulin } \\
\text { concentrations and their } \\
\text { impact on body composition of } \\
\text { HbA1c, HOMA-IR, HOMA B, } \\
\text { HDL *, and Triglycerides. }\end{array}$ & $\begin{array}{l}\text { Did not look at the impact } \\
\text { of HIIT on proinsulin } \\
\text { concentrations nor to } \\
\text { analyze its impact on body } \\
\text { composition of HbA1c, } \\
\text { HOMA-IR, HOMA B, HDL, } \\
\text { and Triglycerides. }\end{array}$ & $\begin{array}{l}\text { Increased } \\
\text { levels of } \\
\text { High density } \\
\text { lipoprotein } \\
\text { (HDL) }\end{array}$ \\
\hline $\begin{array}{l}\text { Backx et al. } \\
(2013)\end{array}$ & $\begin{array}{l}\text { United } \\
\text { Kingdom }\end{array}$ & $\begin{array}{l}\text { Randomized } \\
\text { Controlled } \\
\text { Trial. }\end{array}$ & $\begin{array}{l}\text { HIIT : } 10 \\
\text { Tidak HIIT : } 9\end{array}$ & $\begin{array}{l}\text { Patients with } \\
\text { type } 2 \\
\text { diabetes, aged } \\
\text { 37-57 years. }\end{array}$ & $\begin{array}{l}\text { This study aimed to examine } \\
\text { the effectiveness of the HIIT } \\
\text { treatment program and lipid } \\
\text { profiles of fasting glucose, } \\
\text { fasting insulin, HbA1c, total } \\
\text { cholesterol, HDL *, LDL, } \\
\text { triglycerides and fasting NEFA } \\
\text { in patients with type } 2 \text { diabetes } \\
\text { mellitus. }\end{array}$ & $\begin{array}{l}\text { Did not test the effective- } \\
\text { ness of the HIIT program. } \\
\text { Did not analyze fasting } \\
\text { glucose lipids, pusa insulin, } \\
\text { HbA1c, total cholestrol, } \\
\text { HDL, LDL, triglycerides } \\
\text { and fasting NEFA. Type } 1 \\
\text { diabetes mellitus patient. }\end{array}$ & $\begin{array}{l}\text { Increased } \\
\text { levels of } \\
\text { High density } \\
\text { lipoprotein } \\
\text { (HDL) }\end{array}$ \\
\hline $\begin{array}{l}\text { Madsen et al. } \\
(2016) .\end{array}$ & Denmark & $\begin{array}{l}\text { Randomized } \\
\text { Controlled } \\
\text { Trial. }\end{array}$ & $\begin{array}{l}\text { HIIT : } 13 \\
\text { Con : } 13\end{array}$ & $\begin{array}{l}\text { Patients with } \\
\text { type } 2 \\
\text { diabetes, aged } \\
47-58 \text { years. }\end{array}$ & $\begin{array}{l}\text { Assessed High Intensity Inter- } \\
\text { val Training with independent } \\
\text { intensity training to control } \\
\text { total Glycemic cholesterol, } \\
\text { HDL *, LDL, triglycerides, } \\
\text { BMI, and body fat. } \\
\text { Type } 2 \text { Diabetes Patients }\end{array}$ & $\begin{array}{l}\text { Did not assessed high } \\
\text { intensity interval training. } \\
\text { Does not analyze total } \\
\text { Glycemic values for choles- } \\
\text { terol, HDL, LDL, trigly- } \\
\text { cerides, BMI, and body fat. } \\
\text { Patients with type } 1 \\
\text { diabetes mellitus. }\end{array}$ & $\begin{array}{l}\text { Increased } \\
\text { levels of high } \\
\text { density } \\
\text { lipoprotein } \\
\text { (HDL) }\end{array}$ \\
\hline
\end{tabular}


Adelita et al./ Effect of HIIT in Increasing of HDL Level in Type 2 DM

\section{b. Forest plot}

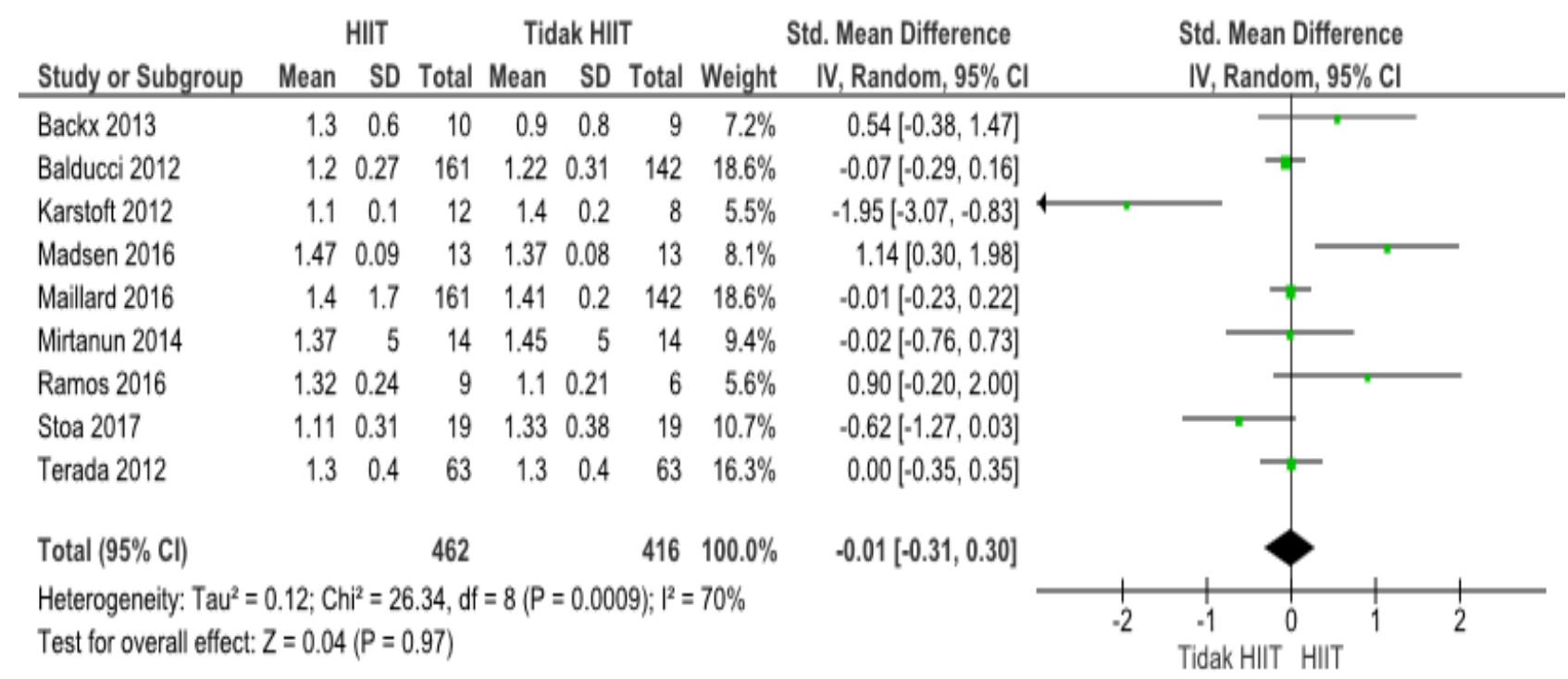

Figure 3. Forest plot of the effect of high intensity interval training on high density lipoproteins

c. Funnel plot

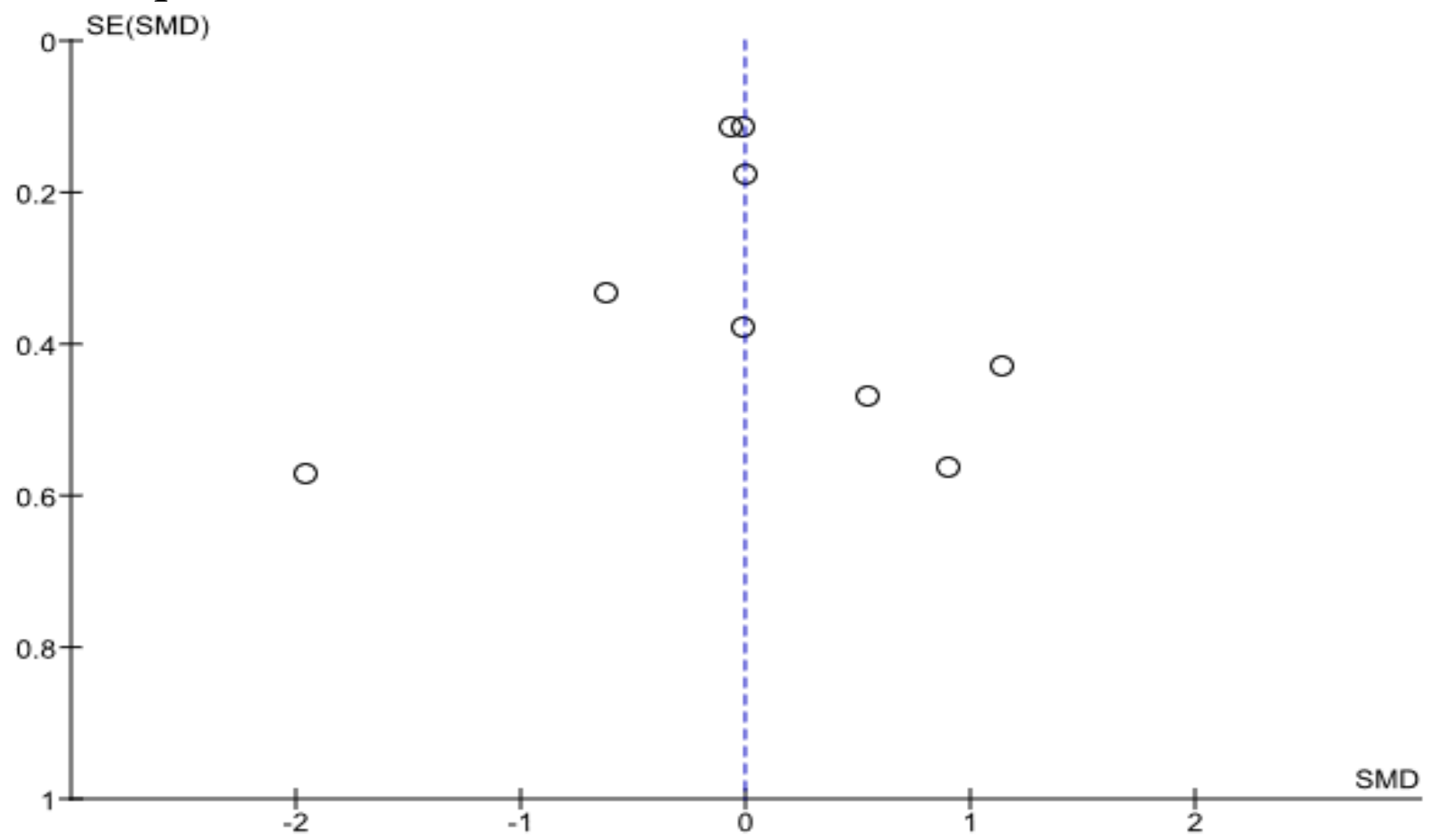

Figure 4. The funnel plot of the effect of high intensity interval training on high density lipoproteins

\section{DISCUSSION}

This systematic study and meta-analysis study's theme is the effect of high intensity interval training on increasing high density lipoproteins levels. This study discusses high intensity lipoproteins data that are consider- 
ed important because of their scarcity. The number of relevant and accessible study published is still small and has data access problems (data duplication) (Murti, 2018).

Confounding factors affect the correlation or effect of exposure to the occurrence of the disease estimated (predicted) by the study is not the same as the correlation or effect that occurs in the target population, a.k.a invalid (incorrect) study results (Murti, 2018). The estimated combined effect of high intensity interval training is processed using RevMan 5.3 with the continuous method. This method is used to analyze the effect size or standardized mean difference in the bivariate data of two groups that have been controlled for confounding factors by randomization.

The systematic study and meta-analysis results are presented in the form of a forest plot and a funnel plot. Forest plots provide an overview of each of the studies examined in the metaanalysis and estimates of the overall results (Murti, 2018). The forest plot shows the amount of variation (heterogeneity) between study results (Akobeng in Murti, 2018) visually.

A funnel plot is a diagram in a metaanalysis used to demonstrate possible publiccation bias. The funnel plot shows the correlation between the study's effect size and the sample size or standard error of the effect size of the various studies studied (Murti, 2018).

Systematic review and metaanalysis in this study were carried out to increase the findings' generalizability and obtain convincing conclusions from various similar study results. High intensity interval training 0.01 times increased high density lipoprotein levels compared to without high density lipoprotein.

A study conducted by Balducci et al (2012) stated that the high-density lipoprotein group increased slightly higher than the non-high-density lipoprotein group. In his study, he recommends a combination of aerobics and high intensity interval training. The slight increase in high density lipoprotein levels is due to the patient's habit of not moving much and often suffering from muscle weakness, resulting in decreased tolerance for activity.

This study is in line with the study conducted by Terada et al (2012) which stated that in the two HIIT and MI-CE groups there was an increase in high density lipoprotein levels which were almost the same but slightly better in HIIT. This is because the psychological response to the exercise stimulus is measured through positive subjective experiences during training intensity and exercise duration. This is very comparable for younger and fitter individuals. Self-efficacy is also an important determinant of compliance.

Hwang et al (2019) supported this study, which stated that the completion rates for HIIT and MICT are comparable to completion rates in other published exercise interventions. In the intervention, HIIT and MIIT were equivalent to $4 \pm 1$ and $4 \pm 1$. This was because the participants were less comfortable with cycling chairs and less comfortable with clothes when cycling.

\section{AUTHOR CONTRIBUTION}

Sela was the main researcher who selects a topic, explored and collected study data. Eti Poncorini Pamungkasari, and Bhisma Murti played a role in analyzing data and reviewing documents of the study.

\section{CONFLICT OF INTEREST}

There is no conflict of interest in this study.

FUNDING AND SPONSORSHIP

This study used the authors' funds. 
ACKNOWLEDGEMENT

The authors would like to express their gratitude to PubMed, ScienceDirect, and Google Scholar database providers.

\section{REFERENCE}

American Diabetes Association (2014). Diagnosis and classification of diabetes mellitus. Diabetes Care,37: 81-S9o.

Ciolac EG, Bocchi EA, Bortolotto LA, Carvalho VO, Greve JMD, Guimaraes GV (2010). Effects of high-intensity aerobic interval training vs. Moderate exercise on hemodynamic, metabolic and neuro-humoral abnormalities of young normotensive women at high familial risk for hypertension. Hypertension Research, 33: 836-843.

Ciolac EG, Mantuani SS, Neiva CM, Verardi C, Pessoa-Filho DM, Pimenta L (2015). Rating of perceived exertion as a tool for prescribing and self regulating interval training: a pilot study. J Sport and Health Sci, 32: 103-108.

Cochrane (2014). RevMan 5.3 User Guide. The Cochrane Collaboration.

Colberg SR, Albright AL, Blissmer BJ, Braun B, Chasan-Taber L, Fernhall B, Regensteiner JG, Rubin RR, Sigal RJ (2010). Exercise and type 2 diabetes: American College of Sports Medicine and the American Diabetes Association: joint position statement. Exercise and type 2 diabetes. Med \& Sci Sports Exerc, 42: 228-230.

Colberg SR, Sigal RJ, Yardley JE, et al. (2016). Physical activity/exercise and diabetes: a position statement of the American Diabetes Association. Diabetes Care, 39: 2065-2079.

Fisher G, Brown AW, Brown MMB, Alcorn A, Noles C, Winwood L, et al. (2015). High intensity interval- vs moderate intensity training for improving cardiometabolic health in overweight or obese males : A randomized controlled trial. PLoS One, 10: 1-15.

Gibala MJ, Little JP, Macdonald MJ, Hawley JA (2012). Physiological adaptations to low-volume, high-intensity interval training in health and disease. $\mathrm{J}$ Appl Physiol, 590: 1077-1084.

Goedecke J, Micklesfield L (2014). The effect of exercise on obesity, body fat distribution and risk for type 2 diabetes. Med \& Sci Sports Exerc, 60: 82-93.

Haidich AB (2010). Metaanalysis in medical research. Hippokratia. https://doi.org/10.5005/jp/books/10519.

Little JP, Gillen JB, Percival ME, Safdar A, Tarnopolsky MA, Punthakee Z, et al. (2011). Low-volume high-intensity interval training reduces hyperglycemia and increases muscle mitochondrial capacity in patients with type 2 diabetes. J Appl Physiol, 111: 1554-1560.

Macleod MR, Tanriver-Ayder E, Hair K, Sena E (2019). Design of metaanalysis studies. In J. E. Barrett (Ed.), Good Research Practice in Non Clinical Pharmacology and Biomedicine. Cham, Switzerland: SpringerOpen.

Mikolajewicz N, Komarova SV (2019). Metaanalytic methodology for basic research: A practical guide. Frontiers in Physiology. https://doi.org/10.3389/fphys.2019.00203.

Mitranun W, Deerochanawong C, Tanaka H, Suksom D (2014). Continuous vs interval training on glycemic control and macro and microvascular reactivity in type 2 diabetic patients. Med \& Sci Sports Exerc, 24: E69-E76.

Murti B (2018). Prinsip dan Metode Riset Epidemiologi (5th ed). Surakarta: Program Studi Ilmu Kesehatan Masyarakat, Program Pascasarjana, Universitas Sebelas Maret.

Naesilla, Argarini R, Mukono IS (2016). Latihan interval intensitas tinggi menurun- 
kan tekanan darah sistol istirahat tetapi tidak menurunkan tekanan darah diastol dan denyut nadi istirahat pada dewasa muda sehat normotensif. Med \& Sci Sports Exerc, 4: 16-24.

Nikolakopoulou A, Mavridis D, Salanti G (2014). How to interpret metaanalysis models: Fixed effect and random effects metaanalyses. Evidence Based Mental Health. https://doi.org/10.1136/eb-2014-101794.

Pan XR, Li GW, Hu YH, Wang JX, Yang WY, An ZX, et al. (2017) Effects of diet and exercise in preventing NIDDM in people with impaired glucose tolerance. The Da Qing IGT and Diabetes Study. Diabetes Care, 20(4): 537-544. PMID: 9096977.

Physical Activity Guidelines Advisory Committee (2018). Physical activity guidelines advisory committee scientific report. Washington, DC, U.S. Department of Health and Human Services.

Shaw JE, Sicree RA, Zimmet PZ (2010). Global estimates of the prevalence of diabetes for 2010 and 2030. Diabetes Res Clin Pract. 87: 4-14.

Siddaway AP, Wood AM, Hedges LV (2019). How to do a systematic review: A best practice guide for conducting and reporting narrative reviews, metaanalyses, and meta-syntheses. Annual Review of Psychology. https://doi.org/10.1146/annurev-psych-010418-102803.
Sluik D, Buijsse B, Muckelbauer R, et al (2012). Physical activity and mortality in individuals with diabetes mellitus: a prospective study and metaanalysis. JAMA Internal Medicine, 172: 12851295.

Snowling NJ, \& Hopkins WG (2006). Effects of different exercise training modes on glucose control and risk factors for complications in type 2 diabetic patients: a metaanalysis. Diabetes Care, 29: 2518-2527.

Tikkanen-Dolenc H, Waden J, Forsblom C et al (2017) FinnDiane Study Group. Physical activity reduces risk of premature mortality in patients with type 1 diabetes with and without kidney disease. Diabetes Care, 40: 1727- 1732. Unger RH (2019) Glucagon physiology and pathophysiology. N. Engl. J. Med, 285(8). 443-449. PMID: 4997492.

Unwin NJ, Shaw J, Zimmet P, Alberti KG (2002). Impaired glucose tolerance and impaired fasting glycaemia: The current status on definition and intervention. Diabetic Medicine, 19: 708723.

WHO (2016) Global Report on Diabetes. WHO. Retrieved from http://www.who. int/diabetes/publications/grd-2016/en/. Accessed 6 April 2016.

Zhang P, Zhang X, Brown J, Vistisen D, Sicree R, Shaw J, Nichols G (2010). Global healthcare expenditure on diabetes for 2010 and 2030. Diabetes Res. Clin. Pract., 87: 293-301. 